\title{
Limitations to photosynthesis at different temperatures in the leaves of Citrus limon
}

\author{
Carlos Pimentel ${ }^{1 *}$, Carl Bernacchi ${ }^{2,3}$ and Steve Long $^{3}$
}

${ }^{1}$ Departamento de Fitotecnia, Universidade Federal Rural do Rio de Janeiro, Seropédica, 23851-970 Brazil. ${ }^{2}$ Center for Atmospheric Sciences, Illinois State Water Survey, Champaign, IL, USA. ${ }^{3}$ Department of Plant Biology, University of Illinois, Urbana, IL 61801, USA. *Corresponding author: greenman@amcham.com.br

Received: 14 May 2007; Returned for revision: 02 July 2007; Accepted: 06 August 2007

The response of $\mathrm{CO}_{2}$ assimilation rate $(A)$ to the intercellular partial pressure of $\mathrm{CO}_{2}\left(C_{\mathrm{i}}\right)$ was measured on intact lemon leaves over a range of temperatures $\left(10\right.$ to $\left.40^{\circ} \mathrm{C}\right)$. The $A / C_{\mathrm{i}}$ response shows how change in the leaf temperature alters the activity of ribulose-1,5-bisphosphate (RuBP) carboxylase-oxygenase (Rubisco) and RuBP regeneration via electron transport. The rate of $A$ reached a maximum of 7.9 to $8.9 \mu \mathrm{mol} \mathrm{m}^{-2} \mathrm{~s}^{-1}$ between 25 and $30^{\circ} \mathrm{C}$, while dark respiration $\left(R_{\mathrm{d}}\right)$ increased with temperature from $0.4 \mu \mathrm{mol} \mathrm{m}^{-2} \mathrm{~s}^{-1}$ at $10^{\circ} \mathrm{C}$ to $1.4 \mu \mathrm{mol} \mathrm{m}^{-2} \mathrm{~s}^{-1}$ at $40^{\circ} \mathrm{C}$. The maximum rates of carboxylation $\left(V_{c, \max }\right)$ and the maximum rates of electron transport $\left(J_{\max }\right)$ both increased over this temperature range from 7.5 to 142 $\mu \mathrm{mol} \mathrm{m} \mathrm{m}^{-2} \mathrm{~s}^{-1}$ and from 23.5 to $152 \mu \mathrm{mol} \mathrm{m} \mathrm{m}^{-2} \mathrm{~s}^{-1}$, respectively. These temperature responses showed that $A$ can be limited by either process depending on the leaf temperature, when $C_{\mathrm{i}}$ or stomatal conductance are not limiting. The decrease in $A$ associated with higher temperatures is in part a response to the greater increase in the rate of oxygenation of RuBP compared with carboxylation and $R_{\mathrm{d}}$ at higher temperatures. Although $A$ can in theory be limited at higher $C_{\mathrm{i}}$ by the rate of triose-phosphate utilization, this limitation was not evident in lemon leaves.

Key words: $A / C_{i}$ curves, gas exchange, lemon

Análise in vivo das limitações da fotossíntese, sob diferentes temperaturas, em folhas de Citrus limon: A resposta da taxa de assimilação de $\mathrm{CO}_{2}(A)$ à pressão parcial de $\mathrm{CO}_{2}\left(C_{\mathrm{i}}\right)$ foi medida em folhas intactas de limão cravo, numa ampla faixa de temperaturas $\left(10\right.$ to $\left.40^{\circ} \mathrm{C}\right)$. A variação na curva $A / C_{\mathrm{i}}$ mostrou como as mudanças na temperatura foliar alteram a atividade da ribulose-1,5-bisfosfato (RuBP) carboxilase-oxigenase (Rubisco) e a regeneração da RuBP, via transporte de elétrons. O valor máximo de $A$ obtido foi de 7.9 a $8.9 \mu \mathrm{mol} \mathrm{m}^{-2} \mathrm{~s}^{-1}$, entre 25 e $30^{\circ} \mathrm{C}$, enquanto a respiração mitocondrial $\left(R_{\mathrm{d}}\right)$ aumentou com a temperatura, de $0.4 \mu \mathrm{mol} \mathrm{m}^{-2} \mathrm{~s}^{-1}$ a $10^{\circ} \mathrm{C}$ até $1.4 \mu \mathrm{mol} \mathrm{m}^{-2} \mathrm{~s}^{-1}$, a $40^{\circ} \mathrm{C}$. A taxa máxima de carboxilação $\left(V_{c, \text { max }}\right)$ e a taxa máxima de transporte de elétrons $\left(J_{\max }\right)$ aumentaram naquela faixa de temperatura, de 7.5 a $142 \mu \mathrm{mol} \mathrm{m}^{-2} \mathrm{~s}^{-1}$, e de $23.5 \mathrm{a} 152 \mu \mathrm{mol} \mathrm{m}{ }^{-2} \mathrm{~s}^{-1}$, respectivamente. A redução em $A$ associada às altas temperaturas é, em parte, uma resposta ao maior aumento na taxa de oxigenação da RuBP, comparada à taxa de carboxilação, e de $R_{\mathrm{d}}$ sob altas temperaturas. Apesar de $A$ poder ser, em teoria, limitada sob elevada $C_{\mathrm{i}}$ pela taxa de utilização de triose-fosfato, essa limitação não foi evidente nas folhas analisadas.

Palavras-chave: curvas $A / C_{\mathrm{i}}$, limão cravo, trocas gasosas

\section{INTRODUCTION}

Temperature is one of the most variable environmental factors, which can suppress photosynthesis both at high and low values. Under global warming scenarios, the study of temperature effects on photosynthesis is essential to predict crop production in the future (Long, 1991). To examine the biochemistry of photosynthesis in leaves, measurement of $\mathrm{CO}_{2}$ assimilation rate $(A)$ in relation to chloroplast $\mathrm{CO}_{2}$ partial pressures $\left(C_{\mathrm{c}}\right)$ would be ideal as this is the $\mathrm{CO}_{2}$ pressure determining the Rubisco carboxylation. However, measuring $C_{\mathrm{c}}$ is 
difficult. Therefore, it has become a common practice to calculate the $\mathrm{CO}_{2}$ partial pressure in substomatal cavities (intercellular $\mathrm{CO}_{2}$ partial pressure, $C_{\mathrm{i}}$ ), based on measurements of gas exchange under different ambient $\mathrm{CO}_{2}$ partial pressures (von Caemmerer, 2000; Long and Bernacchi, 2003). The response of $A$ to $C_{\mathrm{i}}$ under different temperatures can be interpreted in terms of the biochemical processes controlling the response of $A$ (Sage, 1994).

The group of evergreen fruit trees includes numerous horticulturally and economically important crops, as Citrus spp., which are cultivated throughout most tropical and subtropical areas of the world. Although citrus tree thrive in hot, dry environments, leaf photosynthesis has a relatively low temperature optimum of $25^{\circ} \mathrm{C}$ to $30^{\circ} \mathrm{C}$ (Goldschimidt and Koch, 1996). The term evergreen relates to the nondeciduous nature of leaves and, as such, has immediate consequences for leaf longevity and photosynthesis. Broadleaf evergreen citrus leaves are relatively thick with a small proportion of leaf volume occupied by intercellular air space. They have a shiny waxy cuticle particularly on the adaxial surface and stomata are located almost exclusively on the abaxial surface (Goldschimidt and Koch, 1996). Therefore, citrus leaves have low rates of $A$ ( 4 to $8 \mu \mathrm{mol} \mathrm{CO}_{2} \mathrm{~m}^{-2} \mathrm{~s}^{-1}$ seem realistic under optimal conditions), and low stomatal and mesophyll conductances (Lloyd et al., 1992). In addition, its leaves act as a carbohydrate storage organ with slow rates of assimilates export, which in turn can feedback to reduce $A$ (Syvertsen and Lloyd, 1994). Wullschleger (1993) made a retrospective analysis of the $A / C_{i}$ curves of $109 C_{3}$ species and concluded that the maximum rate of carboxylation $\left(V_{c, \text { max }}\right)$ and the lightsaturated rate of electron transport $\left(J_{\max }\right)$ were in general higher for herbaceous annuals plants than for woody perennials. Therefore, the aim of this study was to characterize the $A / C_{\mathrm{i}}$ response and the in vivo calculated photosynthetic parameters in Citrus limon, an evergreen plant with low $A$ values even for $\mathrm{a}_{3}$ plant, estimated from the $A / C_{\mathrm{i}}$ response curves over a range of temperature.

\section{MATERIAL AND METHODS}

Three individuals of Citrus limon L. were germinated and grown in environmentally-controlled greenhouses located at the University of Illinois, Urbana, USA. Plants were grown in a soil-less growth medium (Sunshine Mix \#1, SunGro Horticulture, Bellevue, USA) and were watered regularly. Nutrient additions were given weekly in the form of $300 \mu \mathrm{L} \mathrm{L}^{-1}$ of NPK 15:5:15 (Peters Excel, The Scotts Co., Marysville, USA) to pot saturation. Greenhouse temperature levels were set at $25^{\circ} \mathrm{C}$ for the 16-h photoperiod and $18^{\circ} \mathrm{C}$ for night.

Leaf gas exchange rates were measured using an open gas exchange system with independent $\left[\mathrm{CO}_{2}\right]$ control using a $6 \mathrm{~cm}^{2}$ clamp-on leaf cuvette (LI 6400, LI-COR, Lincoln, USA). The gas-exchange system was zeroed daily using $\mathrm{CO}_{2}$-free air, and leakage of $\mathrm{CO}_{2}$ into and out of the chamber, with a Citrus leaf inside, was determined for the range of $\mathrm{CO}_{2}$ concentrations used in this study and used to correct measured leaf fluxes. The chamber was modified by replacing the peltier external heat sink with a metal block containing water channels, which in turn were connected to a heating/cooling circulating water bath (Endocal RTE-100, Neslab Instruments, Newington, USA). The modified heating/cooling blocks, used in conjunction with the peltier temperature controls, provided leaf temperature control at any preset value between $10-40^{\circ} \mathrm{C}$. Leaf temperature was measured using a chromal-constantin thermocouple pressed to the lower leaf surface. The temperatures reported by this particular thermocouple were cross-checked against standard mercury-in-glass thermometers in a controlled temperature chamber and found to be within $\pm 0.4^{\circ} \mathrm{C}$ (Bernacchi et al., 2003).

Photosynthesis was measured after acclimation of the leaf to temperature (until $A$ was steady-stated and total $\mathrm{CV}$ was lower than 0.3 , at least after $2 \mathrm{~h}$ at each new temperature) at photosynthetic photon flux density (PPFD) between 600 and $800 \mu \mathrm{mol} \mathrm{m} \mathrm{m}^{-2} \mathrm{~s}^{-1}$, which was lightsaturating for this species. Photosynthetic photon flux density was controlled using an artificial quartz halide light source controlled with a quantum sensor located inside the leaf cuvette. The vapor pressure deficit in the cuvette was maintained between 0.5 and $2.0 \mathrm{kPa}$ to prevent stomatal closure by passing the air entering the gas-exchange system through either anhydrous calcium carbonate (Drierite, W.A. Hammond Drierite Company, Xenia, USA) at lower temperatures when humidity was high or by bubbling the air through water for the higher temperatures. Values for $A$ and $C_{\mathrm{i}}$ were calculated using the equations of von Caemmerer and Farquhar (1981). A 
protocol commonly used in determining this $A$ versus $C_{\mathrm{i}}$ response is: firstly, induce photosynthesis at the growth $\mathrm{CO}_{2}$ concentration (36 to $380 \mu \mathrm{mol} \mathrm{mol}^{-1}$ ) and saturating PPFD (between 600 and $800 \mu \mathrm{mol} \mathrm{m} \mathrm{m}^{-2} \mathrm{~s}^{-1}$ ) until $A$ is steadystated (over a 5-min period). Values of $A$ and $C_{\mathrm{i}}$ are recorded and then ambient $\mathrm{CO}_{2}$ partial pressure $\left(C_{a}\right)$ is decreased to 300, 250, 200, 150, 100 and $50 \mu \mathrm{mol} \mathrm{mol}^{-1}$. Upon completion of this sequence, $C_{\mathrm{a}}$ is returned to growth $\mathrm{CO}_{2}$ concentration to check that the original $A$ can be restored and then is increased stepwise to 450, 550, $650,800,1000 \mu \mathrm{mol} \mathrm{mol}{ }^{-1}$. Steady-state photosynthesis needs to be obtained at each step (with a total CV lower than 0.3 , at least after 5 min for each step).

Three replicate measurements of $A / C_{\mathrm{i}}$ curves (Figure 1: $A / C_{\mathrm{i}}$ curve at $25^{\circ} \mathrm{C}$ ) were measured on different plants, at $5^{\circ} \mathrm{C}$ intervals between 10 and $40^{\circ} \mathrm{C}$. The parameters $V_{\text {c,max }}, J_{\text {max }}$ and $R_{\mathrm{d}}$ were estimated using regression analysis of the curves (Figure 2) based on the equations presented in the appendix (Long and Bernacchi, 2003). The temperature responses of $V_{\mathrm{c}, \max }, J_{\max }$, and $R_{\mathrm{d}}$ were plotted from the results of the regression analysis at each measurement temperature from 10 to $40^{\circ} \mathrm{C}$ (e.g., Bernacchi et al., 2001). Data for photosynthesis measured at a $\mathrm{CO}_{2}$ concentration of $370 \mu \mathrm{mol} \mathrm{mol}{ }^{-1}$ was extracted from the curves and plotted as a function of temperature. Using the equations presented by Farquhar et al. (1980), based on $A / C_{i}$ measurements (Figure 1) and thus the calculated response of $V_{c, \text { max }}$ (Figure 2) at the complete range of temperatures, estimations of the temperature response of photosynthesis under non-RuBP limiting conditions was also determined.

Data were subjected to analysis of variance (ANOVA) for temperature effects and means were compared by Student-Newman-Keuls test at 0.05 of probability, when significance was detected.

\section{RESULTS AND DISCUSSION}

Under light saturating conditions photosynthesis for $\mathrm{C}_{3}$ plants is limited by Rubisco capacity, the Rubisco limited phase, as shown in Figure 1. As $C_{i}$ increases above typical levels for this specie, photosynthesis will typically become limited by RuBP regeneration via electron transport, the RuBP limited phase, and by triosephosphate utilization (TPU) at substantially higher $C_{\mathrm{i}}$, the TPU limited phase (Sage, 1994; von Caemmerer, 2000).

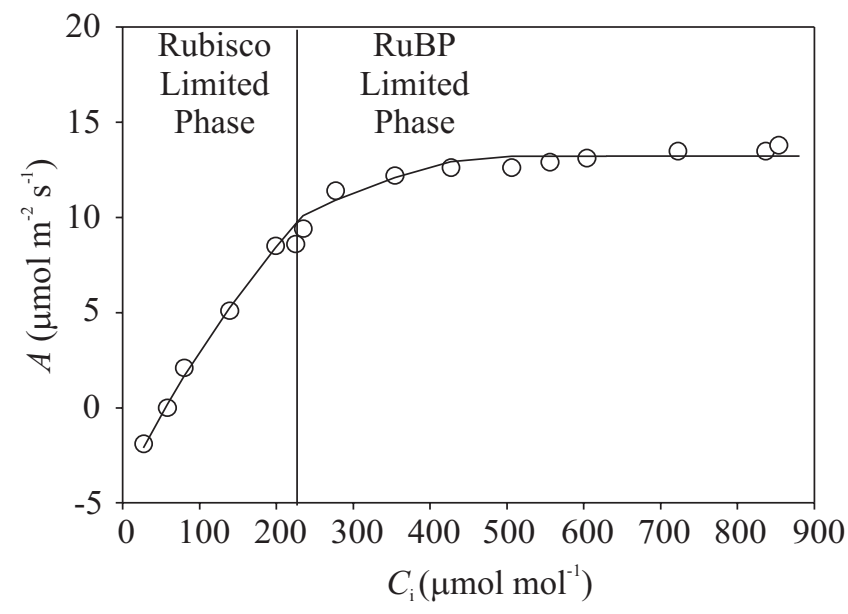

Figure 1. The $A / C_{\mathrm{i}}$ response of Citrus limon at $25^{\circ} \mathrm{C}$. The actual rates of photosynthesis that would be achieved depending on whether Rubisco or RuBP are limiting (in this study triose-phosphate utilization was not limiting).

This last limitation, however, was not observed in this experiment with lemon (Figure 1), as is frequent in fieldbased measurements (Adams et al., 2000). During the electron transport limitation, the RuBP limited phase, $\mathrm{CO}_{2}$ uptake still increases because $\mathrm{CO}_{2}$ out-competes $\mathrm{O}_{2}$ for the available RuBP, but during the triose limitation photosynthesis is no more $\mathrm{CO}_{2}$ dependent (von Caemmerer, 2000).

The results obtained with lemon under temperatures from $10^{\circ} \mathrm{C}$ to $40^{\circ} \mathrm{C}$ showed a maximum values of $A$ between 25 and $30^{\circ} \mathrm{C}$, with 8.9 and $7.9 \mu \mathrm{mol} \mathrm{m} \mathrm{m}^{-2} \mathrm{~s}^{-1}$, respectively, while $R_{\mathrm{d}}$ increased significantly with temperature from 0.4 to $1.5-1.4 \mu \mathrm{mol} \mathrm{m} \mathrm{m}^{-2} \mathrm{~s}^{-1}$ (obtained as in Figure 2). The range of temperature for maximal $A$ measured (Figure $3 \mathrm{~A}$ ) is in agreement with Golschmidt and Koch (1996), who stated that the genus Citrus, which originated in tropical and semitropical regions, have an optimal temperature between $25^{\circ} \mathrm{C}$ to $30^{\circ} \mathrm{C}$. The highest value of $A(8.9 \mu \mathrm{mol}$ $\mathrm{m}^{-2} \mathrm{~s}^{-1}$; Figure $3 \mathrm{~A}$ ) was obtained at $25^{\circ} \mathrm{C}$ and $A$ decreased both above and below this temperature. This is in contrast to $R_{\mathrm{d}}$, which rose with temperature (Figure 3B). The low value of $A$ for the perennial woody Citrus spp. when compared to annual herbaceous plants (Wullschleger, 1993), but also to other perennials fruit crops as Prunus persica, might be attributed to a lower mesophyll conductance $\left(g_{\mathrm{m}}\right)$ or/and low leaf nitrogen present as Rubisco (Lloyd et al., 1992), which can in turn reduce $V_{\mathrm{c}, \max }$ (Long, 1991). 


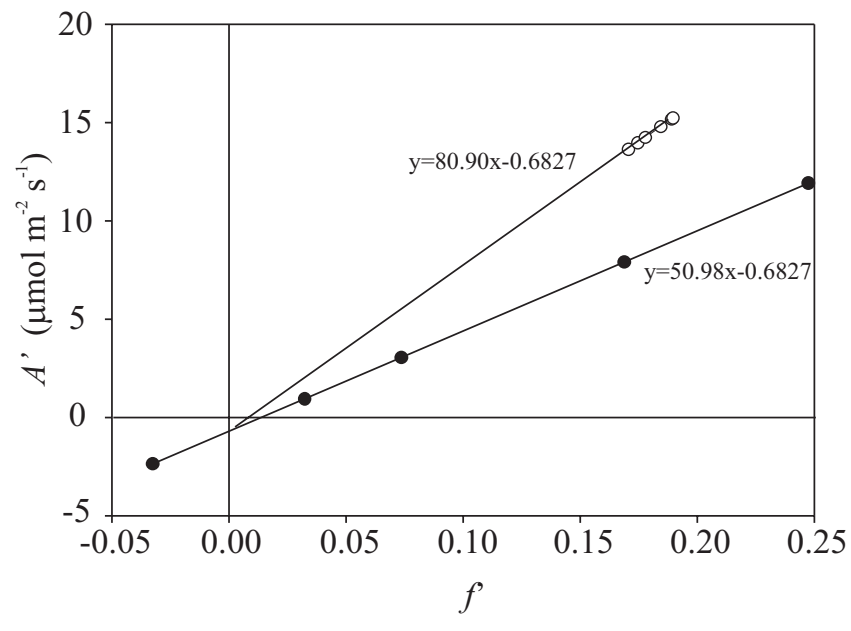

Figure 2. The adjusted $\mathrm{CO}_{2}$ assimilation rate $\left(A^{\prime}\right)$ plotted as a linear function of $f^{\prime}$ (which is a function of $C_{i}$ in the Rubisco limited part of the $A / C_{\mathrm{i}}$ response curve; closed circles) and $g$ ' (which is a function of $C_{\mathrm{i}}$ in the RuBP limited part of the $A / C_{\mathrm{i}}$ response curve; open circles) of Citrus limon at $25^{\circ} \mathrm{C} . V_{\mathrm{c} \text { max }}$ is obtained by the slope and $R_{\mathrm{d}}$ is the intercept of the $A \times f^{\prime}$ linear function, while $R_{\mathrm{d}}$ values is used to solve for $J_{\max }$ in the $A \times g$ ' linear function, as stated by Long and Bernacchi (2003). $n=3 \pm$ SD.

Potentially 50 to $70 \%$ of carbon assimilated in plant biomass is released back to the atmosphere as $\mathrm{CO}_{2}$ during subsequent plant respiration (Baldocchi and Amthor, 2001). The response of $A$ to temperature is parabolic and its decrease at high temperature occurs through numerous potential processes, including increases in $R_{\mathrm{d}}$, decrease in membrane stability, decrease in the specificity factor of Rubisco and an accumulation of carbohydrates (Baldocchi and Amthor, 2001). In addition, the limitation of $A$ imposed by an increase in $g_{\mathrm{m}}$ with temperature suggests that the dominant process(es) determining $g_{\mathrm{m}}$ is not physical, but probably protein-mediated, possibly involving a carbonic anhydrase or aquaporins (Bernacchi et al., 2002; Long and Bernacchi, 2003).

Under non-limiting environmental conditions, in vitro Rubisco activity $\left(V_{c, \max }\right.$ ) for the activated enzyme extracted from citrus leaves is generally in the range of 300 to $400 \mu \mathrm{mol} \mathrm{CO}_{2} \mathrm{mg}$ chlorophyll ${ }^{-1} \mathrm{~h}^{-1}$ ( Vu and Yelenovsky, 1988). These authors equate a $V_{c, \max }$ value of about $75 \mu \mathrm{mol} \mathrm{CO}_{2} \mathrm{mg}$ chlorophyll ${ }^{-1} \mathrm{~h}^{-1}$ for leaves of "Valencia" orange (Citrus sinensis [L.] Osbeck) having a maximum $A$ of $8 \mathrm{mmol} \mathrm{CO}_{2} \mathrm{~m}^{-2} \mathrm{~s}^{-1}$. On the other hand, from an $A / C_{\mathrm{i}}$ plot, Syvertsen and Lloyd (1994) obtained a value

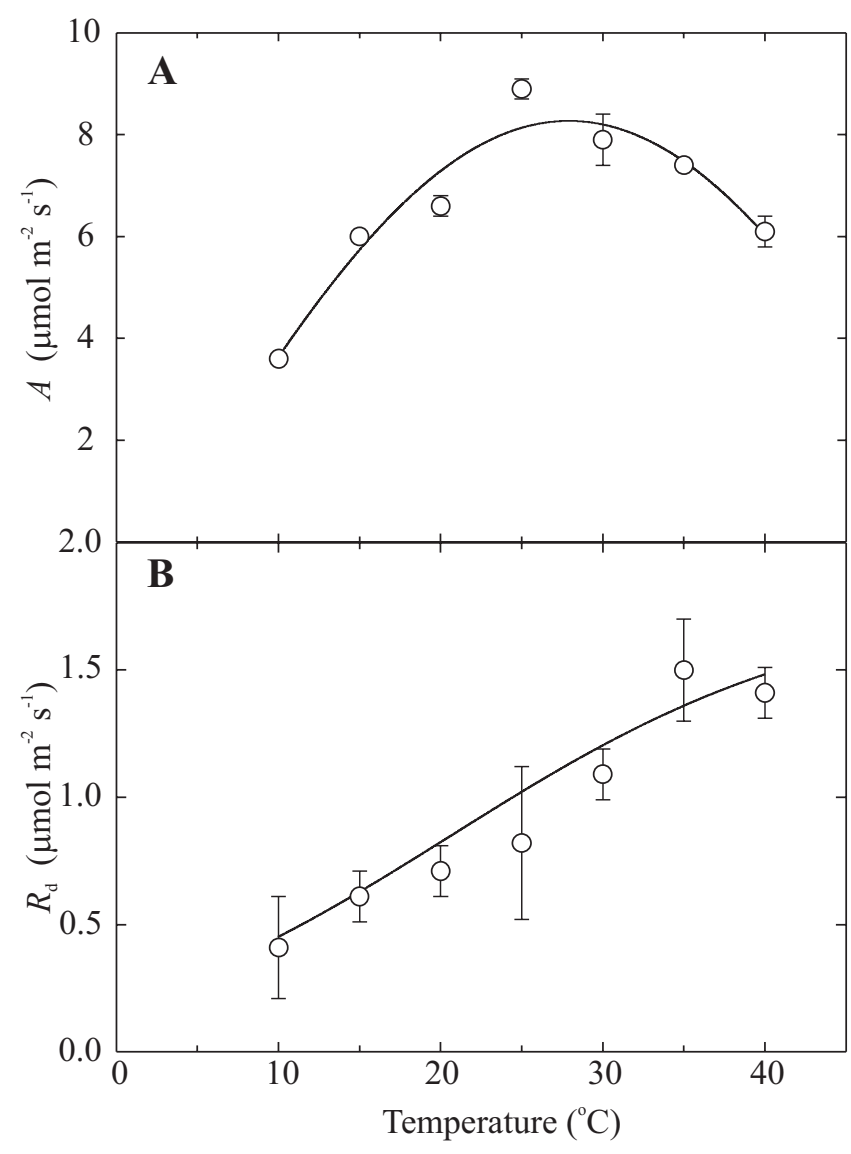

Figure 3. Temperature response of (A) $\mathrm{CO}_{2}$ assimilation rate $(A)$ and $(\mathbf{B})$ dark respiration $\left(R_{\mathrm{d}}\right)$, determined from gas exchange measurements on Citrus limon. $n=3 \pm$ SD.

for $V_{\mathrm{c} \text {,max }}$ varying from 75 to $106 \mu \mathrm{mol} \mathrm{m} \mathrm{m}^{-2} \mathrm{~s}^{-1}$, and a value for $J_{\max }$ varying from 130 to $140 \mu \mathrm{mol} \mathrm{m}{ }^{-2}$ for "Marsh" and "Ruby Red" grapefruit at $25^{\circ} \mathrm{C}$, respectively. The in vivo values of $V_{\mathrm{c}, \max }$ and $J_{\max }$ for $C$. limon at $25^{\circ} \mathrm{C}$ were $55 \mu \mathrm{mol}$ $\mathrm{m}^{-2} \mathrm{~s}^{-1}$ and $87 \mu \mathrm{mol} \mathrm{m} \mathrm{m}^{-2} \mathrm{~s}^{-1}$ (Figure 4A,B), respectively. These values of $V_{c, \max }$ and $J_{\max }$ at $25^{\circ} \mathrm{C}$ are close to the mean values obtained by Wullschleger (1993) for perennials species, i.e. 44 and $97 \mu \mathrm{mol} \mathrm{CO}_{2} \mathrm{~m}^{-2} \mathrm{~s}^{-1}$, respectively, whereas the mean values of these parameters for herbaceous annuals plants are 75 and 154 $\mu \mathrm{mol} \mathrm{CO} \mathrm{m}^{-2} \mathrm{~s}^{-1}$, respectively.

In this study with lemon, the in vivo values of $V_{c, \max }$ and $J_{\max }$ increased significantly with temperature from 7.5 to $142 \mu \mathrm{mol} \mathrm{m} \mathrm{m}^{-2} \mathrm{~s}^{-1}$ (Figure 4A) and from 23.5 to $152 \mu \mathrm{mol}$ $\mathrm{m}^{-2} \mathrm{~s}^{-1}$ (Figure 4B), respectively. In addition, the increase in $V_{\mathrm{c}, \max }$ with temperature is greater than $V_{\mathrm{o}, \max }$ (Figure $4 \mathrm{~A}, \mathrm{C})$, and $V_{\mathrm{o}, \max }$ values varied from 2.4 to $35.7 \mu \mathrm{mol} \mathrm{m}^{-2} \mathrm{~s}^{-1}$ 


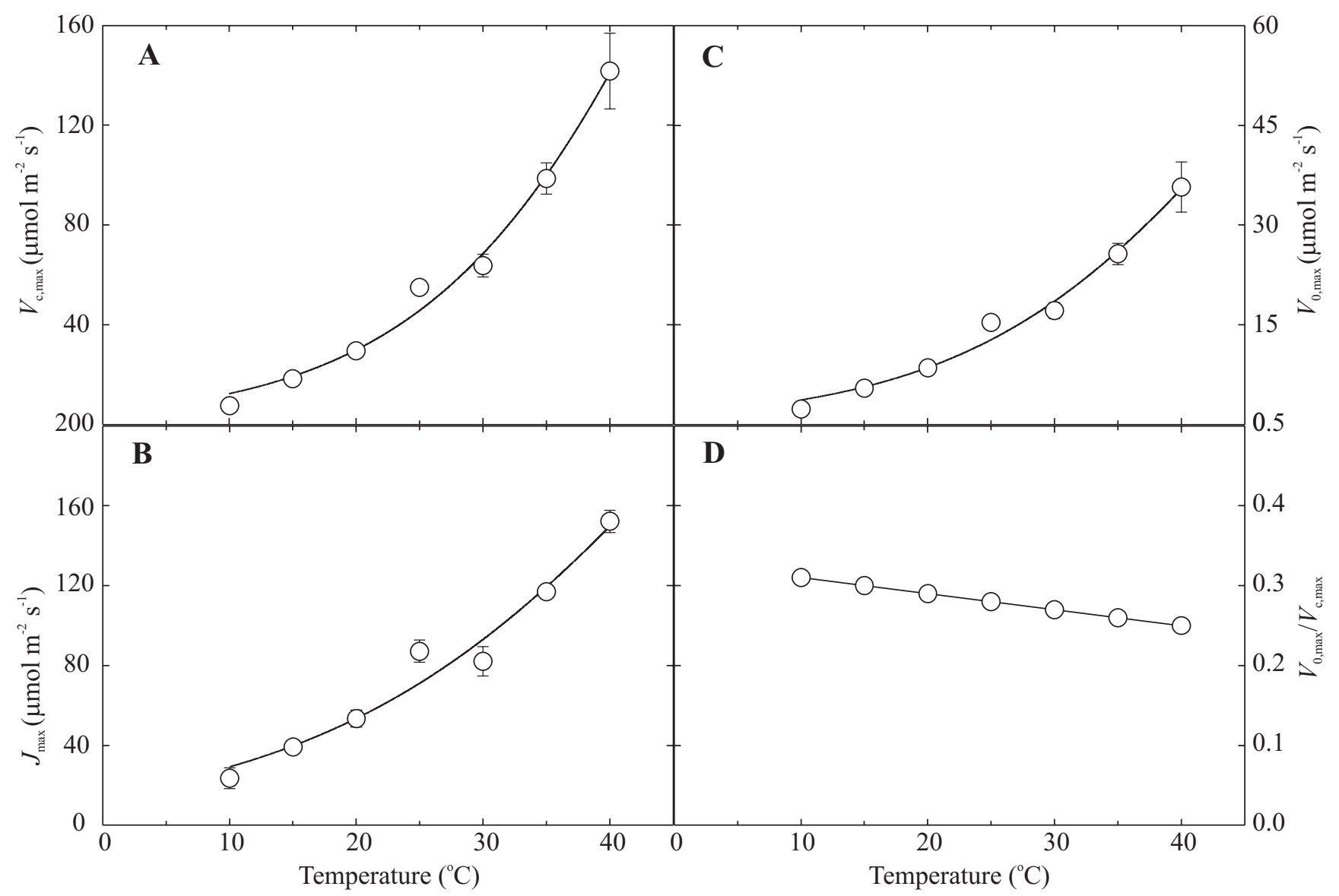

Figure 4. Temperature response of four parameters describing photosynthesis on Citrus limon: (A) response of $V_{c, m a x}$ (the maximum rate of carboxylation); (B) response of $J_{\max }$ (light saturated rate of electron transport); (C) response of $V_{\mathrm{o}, \max }\left(\right.$ the maximum rate of oxygenation); and (D) and the ratio of $V_{\mathrm{c}, \max } / V_{\mathrm{o}, \max }$ versus temperature. $n=3 \pm \mathrm{SD}$.

(Figure 4C). From our measurements, we found that $V_{\text {o,max }}$ $/ V_{c, \max }$ declines with temperature. However, due to the differential effect of temperature on the velocity of carboxylation relative to oxygenation $\left(V_{c} / V_{\mathrm{o}}\right)$, observed $A$ values will actually decline with increasing temperatures due to increased photorespiration (Long et al., 2004). Therefore, the ratio of $V_{\mathrm{o}, \max } / V_{\mathrm{c} \text {, max }}$ is reduced (Figure 4D) at high temperature and there is a greater increases in $V_{\text {c, } \max }$ compared to $V_{\text {o,max }}$, as stated by Bernacchi et al. (2001) and, thus, the proportion of potential carbon uptake lost to photorespiration increases (Long, 1991).

Therefore, depending on temperature $A$ can be limited by very different processes. The amount and activation state of the photosynthetic enzymes, each representing a different limiting process to overall $\mathrm{CO}_{2}$ assimilation, are integral for determining the temperature optimum of photosynthesis.

\section{REFERENCES}

Adam NR, Wall GW, Kimball BA, Pinter, Jr. PJ, LaMorte RL, Hunsaker DJ, Adamsen FJ, Thompson T, Matthias AD, Leavitt SW, Weber AN (2000) Acclimation response of spring wheat in a free-air $\mathrm{CO}_{2}$ enrichment (FACE) atmosphere with variable soil nitrogen regimes. 1. Leaf position and phenology determine acclimation response. Photosynth. Res. 66:65-77.

Baldocchi DD, Amthor JS (2001) Canopy photosynthesis: history, measurements and models. In: Roy J, Saugier B, Mooney HA (eds), Terrestrial Global Productivity. pp.9-31. Academic Press, San Diego.

Bernacchi CJ, Singsaas EL, Pimentel C, Portis AR, Long SP (2001) Improved temperature response functions for models of Rubisco-limited photosynthesis. Plant Cell Environ. 24:253-259. 
Bernacchi CJ, Portis AR, Nakano H, von Caemmerer S, Long SP (2002) Temperature response of mesophyll conductance. Implications for the determination of Rubisco enzyme kinetics and for limitations to photosynthesis in vivo. Plant Physiol. 130:1992-1998.

Bernacchi CJ, Pimentel C, Long SP (2003) In vivo temperature response functions of parameters required to model RuBP-limited photosynthesis. Plant Cell Environ. 26:1419-1430.

Farquhar GD, von Caemmerer S, Berry JÁ (1980) A biochemical model of photosynthetic $\mathrm{CO}_{2}$ assimilation in leaves of $\mathrm{C}_{3}$ species. Planta 149:78-90.

Goldschimidt EE, Koch KE (1996) Citrus. In: Zamski E, Schaffer AA (eds), Photoassimilate Distribution in Plants and Crops. Source-Sink Relationships. pp.825850. Marcel Dekker, New York.

Harley P, Sharkey T (1991) An improved model of $\mathrm{C}_{3}$ photosynthesis at high $\mathrm{CO}_{2}$ : reversed $\mathrm{O}_{2}$ sensitivity explained by lack of glycerate reentry into the chloroplast. Photosynth. Res. 27:169-178.

Long SP (1991) Modification of the response of photosynthetic productivity to rising temperature by atmospheric $\mathrm{CO}_{2}$ concentrations: has its importance been underestimated? Plant Cell Environ. 14:729-739.

Long SP, Bernacchi CJ (2003) Gas exchange measurements, what can they tell us about the underlying limitations to photosynthesis? Procedures and sources of errors J. Exp. Bot. 54:2393-2401.

Long SP, Ainsworth EA, Rogers A, Ort DR (2004) Rising atmospheric carbon dioxide: plants FACE the future. Annu. Rev. Plant Biol. 55:591-628.

Lloyd J, Syvertsen JP, Kriedemann PE, Farquhar GD (1992) Low conductances for $\mathrm{CO}_{2}$ diffusion from stomata to the sites of carboxylation in leaves of woody species. Plant Cell Environ. 15:873-899.

Sage RF (1994) Acclimation of photosynthesis to increasing atmospheric $\mathrm{CO}_{2}$ : the gas exchange perspective. Photosynth. Res. 39:351-368.

Syvertsen JP, Lloyd JJ (1994) Citrus. In: Schaffer B, Andersen PC (eds), Handbook of Environmental Physiology of Fruit Crops. Vol. II: Sub-Tropical and Tropical Crops, pp.65-100. CRC Press, Boca Raton.

von Caemmerer S, Farquhar GD (1981) Some relationships between the biochemistry of photosynthesis and the gas exchange of leaves. Planta 153:376-387.

von Caemmerer S (2000) Biochemical Models of Leaf
Photosynthesis. Techniques in Plant Science $n^{\circ} 2$. CSIRO Publishing, Collingwood.

Vu JCV, Yelenosky G (1988) Water deficit and associated changes in some photosynthetic parameters in leaves of "Valencia"orange (Citrus sinensis [L.] Osbeck). Plant Physiol. 88:375-381.

Wullschleger SD (1993) Biochemical limitations to carbon assimilation in $\mathrm{C}_{3}$ plants - a retrospective analysis of the A/Ci curves from 109 species. J. Exp. Bot. 44:907-920.

\section{APPENDIX}

\section{Model theory}

Farquhar et al. (1980) presented a model of leaf level photosynthesis with two rate limiting steps with a third added by Harley and Sharkey (1991). This model states that at any given internal concentration of $\mathrm{CO}_{2}$, photosynthesis is limited by the slower of three processes: 1) the maximum rate of Rubisco-catalyzed carboxylation (Rubisco-limited $A$ ); 2) the regeneration of RuBP controlled by electron transport rate (electron transport-limited $A$ ); or 3 ) the regeneration of RuBPcontrolled by the rate of triose-phosphate utilization (TPU-limited $A$ ). Both $\mathrm{CO} 2$ and $\mathrm{O} 2$ compete for the Rubisco binding site in the processes known as carboxylation and oxygenation, respectively (Farquhar et al., 1980). To account for the competitive inhibition between $\mathrm{CO}_{2}$ and $\mathrm{O}_{2}, A$ is mathematically expressed as:

$A=v_{c}-0.5 v_{o}-R_{d}$, where $\mathrm{v}_{\mathrm{c}}$ and $\mathrm{v}_{\mathrm{o}}$ are the rates of carboxylation and oxygenation, respectively, and $R_{\mathrm{d}}$ is the mitochondrial respiration (Farquhar et al., 1980).

When $A$ is Rubisco-limited $\left(W_{c}\right.$ ) the velocity of carboxylation can be expressed as:

$W_{c}=v_{c}=\frac{V_{c, \max } \cdot C_{i}}{C_{i}+K_{c}\left(1+O / K_{o}\right)}$,

where $V_{\mathrm{c}, \max }$ is the maximum rate of carboxylation, $\mathrm{O}$ is the oxygen concentration, and $K_{\mathrm{c}}$ and $K_{\mathrm{o}}$ are the MichaelisMenten constants for $\mathrm{CO}_{2}$ and $\mathrm{O}_{2}$, respectively (Farquhar et al., 1980).

The velocity of carboxylation when limited by the rate of electron transport $\left(W_{\mathrm{j}}\right)$ is expressed as stated by von Caemmerer (2000):

$W_{j}=v_{c}=\frac{J \cdot C_{i}}{4.5 C_{i}+10.5 \Gamma^{*}}$, 
where $J$ is the potential rate of electron transport and can be expressed as a function of light saturated rate of electron transport $\left(J_{\max }\right)$, as stated by von Caemmerer (2000):

$J=\frac{J_{\max } \cdot f \cdot I}{f \cdot I+2.1 J_{\max }}$,

where $f$ is the fraction of light not absorbed by functional photosynthetic pigments and $I$ is the photon flux hitting the leaf.

Triose phosphate utilization limited photosynthesis $\left(W_{\mathrm{p}}\right)$ was not a limitation in this study but can occur at low temperatures or high levels of $\mathrm{CO}_{2}$ for others species and is expressed as:

$W_{p}=v_{c}=3 \cdot V_{T P U}$,

where $V_{\text {TPU }}$ is the velocity of triose phosphate utilization, which is multiplied by three to represent three mol CO$_{2}$ that can be fixed for every mol of triose-phosphate made available (Harley and Sharkey, 1991).

Incorporating the three rate limiting steps into equation 1 yields:

$A=\left[1-\Gamma^{*} / C_{i}\right] \cdot \min \left(W_{c}, W_{j}, \frac{W_{p}}{1-\Gamma^{*} / C_{i}}\right)$,

where the term $\Gamma^{*}$ is the $\mathrm{CO}_{2}$ compensation point in the absence of $R_{\mathrm{d}}$. The term $\left[1-\Gamma^{*} / C_{\mathrm{i}}\right]$ represents photorespiration and is derived from the equation:

$v_{o}=\frac{V_{o, \max } \cdot O}{O+K_{o}\left(1+C_{i} / K_{c}\right)}$,

where $V_{\mathrm{o}, \max }$ is the maximum rate of oxygenation (Farquhar et al., 1980; von Caemmerer 2000). Photosynthesis limited by $W_{\mathrm{p}}$ is insensitive to changes in $\mathrm{CO}_{2}$ or $\mathrm{O}_{2}$ and thus the term representing photoinhibition is removed (von Caemmerer, 2000).

From the Rubisco limited portion of the $A / C_{\mathrm{i}}$ curve (integrating equation 2 into equation 1 ), below the inflection point of the curve (obtained by the interception of the adjusted curves for Rubisco limited and RuBP limited phases), the values of $V_{\mathrm{c}, \max }$ and $R_{\mathrm{d}}$ can be calculated from the equation:

$A=\left[\left(1-\Gamma * / C_{i}\right) \cdot \frac{V_{c, \max } \cdot C_{i}}{C_{i}+K_{c}\left(1+O / K_{o}\right)}\right]-R_{d}$,

where $\Gamma^{*}=42.05 \mu \mathrm{bar} ; O=20.9 \mu \mathrm{bar} ; K_{\mathrm{c}}=404.9 \mu \mathrm{bar}$; and $K_{\mathrm{o}}=278.4 \mathrm{mbar}$ at $25^{\circ} \mathrm{C}$ (Long and Bernacchi 2003). For other temperatures, $\Gamma^{*}, K_{\mathrm{c}}$ and $K_{\mathrm{o}}$ are adjusted by the equation parameter $=\exp \left(c-\Delta H_{\mathrm{a}} / R T_{\mathrm{k}}\right)$, where $c$ and $\Delta H_{\mathrm{a}}$ values for each parameter are presented in Bernacchi et al. (2001). The two unknowns $V_{\mathrm{c}, \max }$ and $R_{\mathrm{d}}$ can be solved, as shown by Long and Bernacchi (2003), by plotting $A$ (below the inflection point: Rubisco limited) as a linear function of $f^{\prime}$ (Figure 2):

$A=V_{c}, \max . f^{\prime}-R d$,

where:

$f^{\prime}=\frac{C i-\Gamma^{*}}{C_{i}+K_{c}\left(1+O / K_{o}\right)}$,

In this linear function, $V_{\mathrm{c}, \max }$ is the slope and $R_{\mathrm{d}}$ the intercept (Figure 2).

On the other hand, from the RuBP limited portion of the $A / C_{i}$ curve (using equation 3 into equation 1 ) above the inflection point of the curve (obtained by the interception of the adjusted curves for Rubisco limited and RuBP limited phases), $J_{\max }$ can be calculated from the equation stated by Long and Bernacchi (2003):

$$
A \max =\left[\left(1-\Gamma^{*} / C_{i}\right) \cdot \frac{J . C_{i}}{4.5 C_{i}+10.5 \Gamma^{*}}\right]-R_{d},
$$

Similarly for $V_{c, \text { max }}, J_{\text {max }}$ can be obtained by plotting $A$ (above the inflection point where it is RuBP limited) as a linear function of $C_{\mathrm{i}}$ (i.e. g'), but fixing the $R_{\mathrm{d}}$ value obtained from $V_{c, \max }$ calculations (equation [9]) to avoid large errors in estimated $R_{\mathrm{d}}$ from a linear regression $\left(A \times C_{\mathrm{i}}\right.$, i.e. $\left.g^{\prime}\right)$, due to small errors in the higher rates of $A$ (RuBP limited). Thus, after solving for $R_{\mathrm{d}}$ from the Rubisco limited portion (together with $V_{\mathrm{c}, \max }$ ), the value for $R_{\mathrm{d}}$ can be used in a linear regression (Long and Bernacchi, 2003), together with the high values of $A$ (from RuBP limited portion) in a linear function of $g^{\prime}$ (Figure 2):

$A=J_{\max } \cdot g^{\prime}-R d$,

where:

$g^{\prime}=\frac{C_{i}-\Gamma^{*}}{4.5 C_{i}+10.5 \Gamma^{*}}$,

where $J_{\max }$ is the slope in this linear function (Figure 2).

Finally, $V_{\mathrm{o} \text { max }}$ can be solved by the equation:

$V_{o, \max }=\frac{V_{c, \max } \cdot K_{o} \cdot \Gamma^{*}}{0.5 K_{c} . O}$,

where $V_{\mathrm{c}, \max }, K_{\mathrm{o}}, \Gamma^{*}, K_{\mathrm{c}}$ and $O$ are either known or solved using previous equations. 